\title{
MENURUNKAN KADAR KOLESTEROL DARAH DENGAN GEL ALOE VERA LINN
}

\author{
REDUCING BLOOD CHOLESTEROL LEVEL WITH ALOE VERA LINN GEL
}

\author{
Evelin Malinti ${ }^{1}$, Susy A. Jael ${ }^{2}$ \\ ${ }^{1}$ Fakultas IImu Keperawatan, Universitas Advent Indonesia \\ ${ }^{2}$ Adventist University of the Philippines \\ Email: evelinmalinti@yahoo.com
}

\begin{abstract}
ABSTRAK
Pendahuluan: Kolesterol merupakan susbtansi yang dibutuhkan tubuh; namun dalam jumlah berlebihan dalam darah, kolesterol menjadi resiko gangguan jantung dan penyakit pembuluh darah. Kandungan fitokimia pada aloe vera atau di Indonesia dikenal sebagai lidah buaya berpotensi untuk menurunkan kadar kolesterol darah. Tujuan: Penelitian ini bertujuan untuk mengivestigasi pengaruh gel aloe vera pada kadar total kolesterol darah klien dengan hypercholesterolemia. Metode: Penelitian ini menggunakan quasi experimental dengan pre-test dan post-test design. Sebanyak 30 responden dipilih dengan dengan purposive sampling yang kemudian dibagi dalam dua kelompok intervensi, 15 responden pada setiap kelompok. Kelompok I diberi 100 g gel aloe vera setiap pagi sedangkan kelompok II diberi $100 \mathrm{~g}$ gel aloe vera di pagi hari dan $100 \mathrm{~g}$ gel aloe vera disore hari, intervensi ini dilakukan selama 7 hari. Kadar total kolesterol darah diperiksa sebelum dan sesudah 7 hari intervensi. Hasil: Ratarata kadar total kolesterol darah sebelum terapi pada kelompok I adalah $224.53 \mathrm{mg} / \mathrm{dL}$ menjadi $196.67 \mathrm{mg} / \mathrm{dL}$ setelah terapi. Pada kelompok II, mengalami penurunan dari $223.73 \mathrm{mg} / \mathrm{dL}$ sebelum terapi menjadi $201.27 \mathrm{mg} / \mathrm{dL}$ setelah terapi. Hasil uji paired ttest menunjukkan penurunan signifikan pada kedua kelompok dengan $p=<.05$. Diskusi: Penurunan kadar kolesterol darah setelah terapi aloe vera dikarenakan oleh komposisi fitokimia yang berperan sebagai antioksidan, menghambat stress oksidasi dan menghambat absorpsi kolesterol dari saluran cerna.
\end{abstract}

Kata Kunci: aloe vera, kolesterol darah

\begin{abstract}
Introduction: Cholesterol is a substance required by the body; however in excessive amounts in the blood, cholesterol is a risk for heart problems and vascular diseases. Phytochemical content in aloe vera or in Indonesia known as "lidah buaya" has the potential to lower blood cholesterol levels. Aim: This study aims to investigate the effect of aloe vera gel on blood total cholesterol level of clients with hypercholesterolemia. Methods: This study utilized the quasi-experimental with pretest and post-test design. A total of 30 respondents were selected by purposive sampling and divided into two intervention groups, 15 respondents in each group. Group I was given $100 \mathrm{~g}$ of aloe vera gel every morning, while group II was given 100 $\mathrm{g}$ of aloe vera gel in the morning and $100 \mathrm{~g}$ of aloe vera gel late afternoon, these interventions were performed for 7 days. Total blood cholesterol levels checked before and after the 7-day intervention. Results: The mean of blood total cholesterol level before therapy in group I was 224. $53 \mathrm{mg} / \mathrm{dL}$ and becomes $196.67 \mathrm{mg} / \mathrm{dL}$ after. In group II, it decreased from $223.73 \mathrm{mg} / \mathrm{dL}$ before therapy to $201.27 \mathrm{mg} / \mathrm{dL}$ after therapy. The result of paired t-test showed a significant reduction in both groups, $p=$ $<$. 05. Discussion: The reduction in blood cholesterol levels after aloe vera therapy due to its composition of phytochemicals that act as antioxidants, inhibiting oxidative stress and prevents the absorption of cholesterol from the digestive tract.
\end{abstract}

Keywords: Aloe vera, blood cholesterol

JURNAL

SKOLASTIK KEPERAWATAN

Vol. 2, No.2

Juli - Desember 2016

ISSN: $2443-0935$

E-ISSN: $2443-1699$ 


\section{PENDAHULUAN}

Kolesterol adalah substansi yang dibutuhkan tubuh untuk sintesis hormon dan pembentukkan membran sel. Selain itu, sejumlah kolesterol juga dibutuhkan untuk transportasi asam lemak dan produksi vitamin D (Center for Health Protection (CHP), 2011). Kolesterol dalam tubuh diperoleh dalam dua cara: $80 \%$ diproduksi oleh liver dan sisanya berasal dari konsumsi produk hewani seperti daging, ikan, telur dan susu (Scanlon \& Sanders, 2011).

Dalam jumlah yang sesuai, kolesterol melakukan fungsi pentingnya, namun dalam jumlah berlebihan menimbulkan masalah kesehatan yang tidak diinginkan (Bellows \& Moore, 2012). Lebih lanjut dijelaskan bahwa level aman kadar kolesterol pada manusia tergantung pada faktor resiko individu seperti kadar antioksidan, riwayat genetik, stress, kurang aktivitas, kebiasaan merokok dan tekanan darah tinggi (Porth, 2011). Kadar total kolesterol darah yang diinginkan bila < $200 \mathrm{mg} / \mathrm{dL}$, dan dinyatakan sebagai batas tinggi (borderline high) antara 200-239 $\mathrm{mg} / \mathrm{dL}$, dan tinggi bila kadar mencapai $\geq 240$ $\mathrm{mg} / \mathrm{dL}$ (Boe, 2012).

Kadar kolesterol darah melebihi nilai normal disebut hiperkolesterolemia atau hiperlipidemia. Hiperkolesterolemia dapat menyebabkan perkembangan plak atherosclerosis pada dinding pembuluh darah yang selanjutnya menghambat aliran darah ke organ-organ vital seperti jantung dan otak (Daniels \& Nicoll, 2012).

Pembentukan atheroma didinding pembuluh darah diawali dengan oksidasi kolesterol. Hal ini terjadi oleh karena kondisi stress oksidatif yaitu terjadi ketidakseimbangan antara produksi reactive oxygen species (ROS) dengan antioksidan dalam tubuh (Amany \& Shaker, 2014).

Penanganan hiperkolesterolemia dimulai dengan memilih diet rendah lemak dan meningkatkan aktifitas fisik. Berhenti merokok, menghindari alkohol, dan menurunkan berat badan juga sangat dianjurkan (CHP, 2011). Selain hal-hal tersebut, meningkatkan konsumsi antioksidan dapat menghambat atau mencegah stress oksidatif, dan melindungi dari berbagai penyakit kronis. Antioksidan secara alami dapat diperoleh dari makanan yang berasal dari tumbuh-tumbuhan (Shebis, et al., 2013).

Aloe vera atau yang dalambahasa Indonesia disebut "lidah buaya" dikenal sebagai salah satu tanaman obat yang memiliki banyak manfaat kesehatan. Fitokimia yang terkandung dalam aloe vera terutama senyawa phenolics (seperti flavonoids, saponins, dan terpenoid) dan glucomanan menarik perhatian karena aktifitas antioksidan yang tinggi (Sharrif \&Verma, 2011).

Menurut Agrawal (2011), karena kemampuan antioksidatif, flavonoids memiliki efek terhadap kesehatan system pembuluh darah. Flavonoid menghambat absorbsi lemak dari saluran pencernaan dan berperan penting dalam mengurangi stress oksidatif, meningkatkan metabolisme kolesterol di liver. Dengan cara yang hampir sama saponin mampu menurunkan kolesterol dengan berikatan dengan garamgaram empedu dan kolesterol di usus halus dan menghambat resbsorpsi kolesterol (Norton, 2011). Kharwal, et al. (2012) menjelaskan bahwa saponins mempengaruhi metabolisme kolesterol di liver. Saponins menunjukkan aktivitas hipolipidemik yang tinggi yang menyebabkan penurunan kadar lemak dan kolesterol darah.

Selanjutnya, Gato, Takahasi, Hirai and Kawada (2010), menyatakan bahwa terpenoids dapat memodulasi aktifitas faktor transkripsi ligan-dependent yang merupakan sensor yang berhubungan dengan makanan berlemak untuk mengontrol homeostasis. Konsumsi terpenoid setiap hari dapat bermanfaat dalam penanganan obesitas yang memicu gangguan metabolik seperti diabetes, hiperlipidemia, dan penyakit kardiovaskular. 


\section{BAHAN DAN METODE PENELITIAN}

Penelitian ini merupakan quasi-experimental dengan pre test- post test design. Pengambilan sample menggunakan purposive sampling. Data yang diperoleh di analisa dengan SPSS menggunakan paired t-test, dan independent t-test, serta mengukur effect size dengan cohen's $d$.

Responden dibagi rata dalam 2 kelompok yaitu kelompok I menerima $100 \mathrm{~g}$ gel aloe vera per hari dan kelompok II menerima 200 $\mathrm{g}$ gel aloe vera per hari. Kedua kelompok memakan gel aloe vera sebanyak $100 \mathrm{~g}$ di pagi hari sebelum makan pagi, dan kelompok II memakan dosis $100 \mathrm{~g}$ gel aloe vera berikutnya pada sore hari sebelum makan malam.

Gel aloe vera didapat dari mengupas daun aloe vera, mencuci dengan air mengalir beberapa kali sampai semua getah kuning hilang. Setelah itu gel di potong dadu dan ditimbang menggunakan timbangan digital sebanyak $100 \mathrm{~g}$ per dosis yang disiapkan dalam gelas kaca dan siap dibagikan kepada responden.

Pemeriksaan total kolesterol darah dilakukan sebelum dan sesudah 7 hari terapi gel aloe vera setelah responden menjalani puasa selama 10 jam.

\section{HASIL}

Dari total 107 responden berusia 30-60 tahun yang menjalani screening test untuk kadar kolesterol 56 orang responden yang memenuhi criteria, dan 30 orang diantaranya menandatangani informed consent untuk berpartisipasi dalam 7 hari terapi gel aloe vera. Ke-30 responden dibagi kedalam 2 kelompok terapi gel aloe vera secara merata dengan pencambutan undi.

Perbedaan rata-rata kadar total kolesterol darah antara kedua kelompok dapat dilihat dalam tabel 1
Tabel 1 Perbedaan rata-rata pre test kadar total kolesterol antara kelompok $100 \mathrm{~g}$ dan $200 \mathrm{~g}$ gel aloe vera.

\begin{tabular}{ccccc}
\hline Group & Mean & SD & $t$ & $p$ \\
\hline $\mathbf{1 0 0 ~ g}$ & 224.53 & 20.87 & .102 & .920 \\
& & & & \\
$\mathbf{2 0 0 ~ g}$ & 223.73 & 22.26 & & \\
\hline
\end{tabular}

Perbedaan rata-rata kadar total kolesterol darah antara hasil pre test dan post test pada kedua kelompok setelah 7 hari terapi gel aloe vera ditunjukkan pada tabel 1.2.

Tabel 2 Perbedaan kadar total kolesterol darah pre dan post terapi 7 hari gel aloe vera pada kelompok $100 \mathrm{~g}$ dan $200 \mathrm{~g}$.

\begin{tabular}{lccccc}
\hline Group & Mean & SD & $t$ & $P$ & $\mathrm{~d}$ \\
\hline $100 \mathrm{~g}$ & & & & & \\
Pre & 224.53 & 20.87 & 4.490 & .001 & 1.16 \\
Post & 196.67 & 23.17 & & & \\
$200 \mathrm{~g}$ & & & & & \\
Pre & 223.73 & 22.26 & 5.458 & .000 & 1.40 \\
Post & 201.27 & 15.58 & & &
\end{tabular}

Sedangkan perbedaan skor pencapaian penurunan kadar total kolesterol darah antara kedua kelompok dapat dilihat dalam tabel 3

Tabel 3 Perbedaan skor pencapain penurunan kadar kolesterol antara kelompok $100 \mathrm{~g}$ dan $200 \mathrm{~g}$ gel aloe vera

\begin{tabular}{cccccc}
\hline Group & Mean & SD & $t$ & $p$ & $\mathrm{D}$ \\
\hline $\mathbf{1 0 0} \mathbf{~ g}$ & 27.87 & 24.04 & .725 & .475 & .265 \\
$\mathbf{2 0 0} \mathbf{g}$ & 22.47 & 15.94 & & & \\
& & & & & \\
\hline
\end{tabular}

\section{PEMBAHASAN}

Rata-rata kadar total kolesterol darah pada kelompok $100 \mathrm{~g}$ aloe vera sebelum terapi adalah $224.53 \mathrm{mg} / \mathrm{dL}$ dan pada kelompok $200 \mathrm{~g}$ aloe vera adalah $223.73 \mathrm{mg} / \mathrm{dL}$. Independent t-test untuk melihat perbedaan rata-rata kadar total kolesterol darah antara kedua kelompok sebelum terapi di tabel 1.1 
memperlihatkan $p=.920$ yang berarti tidak signifikan. Hal ini menunjukkan bahwa kedua kelompok "comparable".

est untuk rata-rata kadar total kolesterol darah sebelum dan sesudah terapi pada kelompok $100 \mathrm{~g}$ gel aloe vera $\mathrm{p}=.001 \mathrm{dan}$ cohen's d=1.16. Pada kelompok $200 \mathrm{~g}$ aloe vera $p=.000$ dengan cohen's $d=1.40$. Hal ini mengindikasikan bahwa terdapat perbedaan signifikan pada hasil kadar total kolesterol darah antara sebelum dan sesudah terapi aloe vera baik pada kelompok $100 \mathrm{~g}$ maupun kelompok $200 \mathrm{~g}(\mathrm{p}=<.005)$ dengan ukuran efek yang besar $(d>.8=$ large effect size). Hasil ini menyatakan bahwa terapi $100 \mathrm{~g}$ dan $200 \mathrm{~g}$ gel aloe vera selama 7 hari efektif dalam menurunkan kadar total kolesterol darah.

Hasil ini konsisten dengan penelitian medis yang pernah dilakukan dimana aloe vera didapati menurunkan kadar kolesterol pada pasien dengan penyakit jantung (Manvitha \& Bidya, 2014). Penelitian lain yang dilakukan oleh Mohamed (2011) yang menginvestigasi efek antidiabetes, antioksidatif dan antihiperkolesterolemia aloe vera pada tikus diabetes menunjukkan penurunan signifikan pada serum glukosa dan total kolesterol.

Efek pengobatan yang dimiliki oleh aloe vera ini merupakan aksi sinergi dari berbagai fitokimia yang terkandung didalamnya (Haman, 2008) seperti glukomanan, acemanan, saponin, flavonoid dan lain-lain yang berpotensi sebagai antioksidan (Sharrif \& Verma, 2011). Sood, Baker, dan Coleman (2008) menyimpulkan dalam penelitian mereka bahwa glucomanan memiliki efek yang bermanfaat dalam menurunkan total kolesterol, low density lipoprotein (LDL), triglycerida, berat badan, dan gula darah puasa. Fitokimia yang bersifat antioksidan memainkan peran sebagai faktor pelindung terhadap penyakit yang berhubungan dengan stress oksidatif (Preedy, 2014). Selain fungsi antioksidan, fitokimia dalam aloe vera memiliki kemampuan untuk menghambat reabsorpsi kolesterol dari saluran cerna (Norton, 2011).
Pada tabel 3 ditunjukkan rata-rata skor pencapaian penurunan kadar total kolesterol darah kedua kelompok. Kelompok $100 \mathrm{~g}$ aloe vera memiliki skor pencapaian 27.87 $(\mathrm{SD}=24.04)$ sedangkan kelompok $200 \mathrm{~g}$ aloe vera memiliki skor pencapaian 22.47 $(\mathrm{SD}=15.94)$. independent t-test pada ratarata skor pencapain kedua kelompok menghasilkan $\mathrm{p}=.475$.

Dari hasil tersebut dapat dilihat bahwa penurunan total kolesterol darah lebih tinggi (27.87) pada kelompok $100 \mathrm{~g}$ aloe vera dibanding pada kelompok $200 \mathrm{~g}$ aloe vera (22.47), dengan ukuran efek kecil ( $d=.265)$. Namun, perbedaan skor pencapaian antara kedua kelompok tidak siknifikan $(p=.475)$. Hal ini memberi implikasi bahwa dosis $100 \mathrm{~g}$ maupun $200 \mathrm{~g}$ gel aloe vera memberi efek yang sama pada kadar total kolesterol darah.

Penelitian sebelumnya yang dilakukan oleh Sianipar dan Insnawati, (2012) menunjukkan bahwa aloe vera menyebabkan peningkatan high density lipoprotein cholesterol (HDL-C) yang mungkin menjadi alasan tidak adanya perbedaan signifikan pada kedua dosis.

Mengacuh pada beberapa penelitian sebelumnya, hasil dari penelitian ini terlihat bertentangan. Sebuah penelitian (Chandrakar, Palekar, Chirade \& Hafiz, 2008) yang mengevaluasi efek dari aloe vera dengan dosis yang berbeda pada reptil (calotes vesicolor Duadin)hiperkolesterol. Dosis yang digunakan adalah 3, 4, 5, and 6 $\mathrm{mg} / \mathrm{kg}$ berat badan selama 21 hari terapi. Pada hari ke 22 hasil kolesterol darah reptil di kelompok dosis 4,5, and $6 \mathrm{mg} / \mathrm{kg}$ berat badan mengalami penurunan signifikan, dengan penurunan terbesar pada kelompok dosis $6 \mathrm{mg} / \mathrm{kg}$ berat badan. Penurunan terbesar kedua dicapai oleh kelompok dosisi $5 \mathrm{mg} / \mathrm{kg}$ berat badan diikuti oleh dosis 4 $\mathrm{mg} / \mathrm{kg}$ berat badan.

Penelitian lain yang dilakukan pada kelinci (Channa, et al., 2014), menunjukkan bahwa dosis $300 \mathrm{mg} / \mathrm{kg}$ dan dosis $400 \mathrm{mg} / \mathrm{kg}$ memberi hasil yang sama pada penurunan kolesterol setelah 7 hari terapi, sedang pada hari ke 14 kedua dosis ini memberi 
penurunan secara bertahap dan penurunan tertinggi dihasilkan oleh dosis $200 \mathrm{mg} / \mathrm{kg}$. Pada akhirnya, dihari ke 21, dosis 300 and $400 \mathrm{mg} / \mathrm{kg}$ membawa perubahan yang sama pada kadar kolesterol darah.

Penelitian lain menginvestigasi efek dosis $100 \mathrm{~g}$ and $200 \mathrm{~g}$ jus aloe vera selama 14 hari terhadap low density lipoprotein (LDL)cholesterol dan high density lipoprotein (HDL) cholesterol pada wanita dislipidemia. Hasilnya menunjukkan bahwa pada kelompok dosis $200 \mathrm{~g}$ jus aloe vera terjadi penurunan signifikan kadar LDL dan peningkatan signifikan kadar HDL. Sedangkan di kelompok $100 \mathrm{~g}$ jus aloe vera, terjadi penurunan signifikan kadar LDL namun tidak ada perubahan signifikan pada HDL (Sianipar \& Isnawati, 2012).

\section{KESIMPULAN}

Berdasarkan pada hasil penelitian, dapat disimpulkan bahwa terapi 7 hari dengan gel aloe vera baik dosis $100 \mathrm{~g}$ maupun dosis 200 $\mathrm{g}$ efektif menurunkan kadar total kolesterol darah. Semakin besar dosis tidak memberi pengaruh besar pada kadar kolesterol darah. Namun, perlu penelitian lebih jauh mengenai efek perbedaan dosis pada lipid profile lain seperti kadar LDL, HDL maupun trigliserida.

\section{REFERENSI}

Agrawal, A. D. (2011). Pharmacological activities of flavonoids: A review. International Journal of Pharmaceutical Sciences and Nanotechnology, 4(2), 1394-1395.

Amany, B. M., \& Shaker, A. M. (2014). Natural antioxidant as antihypercholesterolemia. INTECH open science.

Bellows, L., \& Moore, R. (2012). Dietary fat and cholesterol. Food and Nutrition Series. Colorado State University Extension. 5/96 (online) available: http://extension.colostate.edu/docs/pubs /foodnut/09319.pdf

Boe, G. P. (2012-August). Cholesterol. Journal of Continuing Education Topics \& Issues, 14(3), 92.

Center for Health Protection, (2011). Be cholesterol smart. Non-Communicable Disease Watch. 4 (9). 1-6

Chandrakar, M., Palekar, S., Chirade, S., \& Hafiz, S. A. M. (2008) Hypocholesterolemic effect of Aloe Vera (L.) extract on high cholesterol fed calotes versicolor daudin. Asian J. Exp. Sci., 22(3), 295-298.

Channa, A. A., Soomro, S. A., Korejo, R. A., Khaskeli, B. A., Qureshi, T. A., Shah, I. A., Kalhoro, N. A., \& Maheswari, H. K.. (2014). Effects of chronic administration of Aloe Vera extract on plasma biochemistry in rabbit. International Journal of Medicine and Medical Sciences, 6(8), 183-189.

Daniels, R., \& Nicoll, L. H. (2012). Contemporary Medical Surgical Nursing ( $2^{\text {nd }}$ ed). USA: Cengage Learning.

Gato, T., Takahashi, N., Hirai, S., \& Kawada, T. (2010). Various terpenoids derived from herbal and dietary plants function as PPAR modulators and regulates carbohydrates and lipid metabolism. Hindawi Publishing Corporation. PPAR Research. Doi:10.1155/2010/483958

Hamman J. H. (2008). Composition and applications of Aloe Vera leaf gel. Molecules, 13, 1599-1616. DOI: $10.3390 /$ molecules 13081599 
Kharwal, H., Panthari, P., Pant, M. K., Kharkwal, H., Kharkwal, A. C., \& Joshi, D. D. (2012). Foaming glycosides: A review. IOSR Journal of Pharmacy, 2(5), 23-28.

Manvitha, K., \& Bidya, B. (2014). Aloe vera: a wonder plant its history, cultivation and medicinal uses. Journal of Pharmacognosy and Phytochemistry. 2(5), 85-88.

Mohamed, E. A. K. (2011). Antidiabetic, antihypercholestermic and antioxidative effect of Aloe Vera gel extract in alloxan induced diabetic rats. Australian Journal of Basic and Applied Sciences, 5(11), 1321-1327.

Norton, K. J. (2011). Phytochemicals: health benefits of saponins. Health Articles, September 17, 2011. (online) Available: http://kylenorton.healthblogs.org/2011/0 9/17/ phytochemicals-12-healthbenefits-of-saponins

Porth, C. M., (2011). Essential of pathophysiology: Concept of altered health states. USA: Lippincott Williams \& Wilkins.

Preedy, V. R. (2014). Diabetes: Oxidative stress and dietary antioxidants. USA: Elsevier
Scanlon, V., \& Sanders T. (2011). Essentials of anatomy and physiology ( $\left.7^{\text {th }} \mathrm{ed}\right)$. Philadelphia, PA: F.A. Davis Co.

Sharrif, M. M., \& Verma, S. K. (2011). Aloe Vera their chemicals composition and applications: A review. Int J Biol Med Res, 2(1), 466-471.

Shebis, E., David Iluz, D., Kinel-Tahan, Y., Dubinsky, Z., \& Yehoshua, Y. (2013). Natural Antioxidants: Function and Sources. Food and Nutrition Sciences. 4. 643-649.

Sianipar, Y., \& Isnawati, M. (2012). Pengaruh pemberian jus lidah buaya (Aloe Vera) terhadap kadar kolesterol low density lipoprotein (LDL) dan high density lipoprotein (HDL). Journal of Nutrition College, 1 (1), 747-761.

Sood, N., Baker, W. L., \& Coleman, C. I. (2008). Effect of glucomannan on plasma lipid and glucose concentrations, body weight, and blood pressure: Systematic review and meta-analysis. American Journal Clinical Nutrition, 88, 1167-75. 